\title{
SALT STRESS ON PHYSIOLOGY, BIOMETRY AND FRUIT QUALITY OF GRAFTED Passiflora edulis
}

\author{
ESTRESSE SALINO NA FISIOLOGIA, BIOMETRIA E QUALIDADE DE FRUTOS DE \\ Passiflora edulis ENXERTADO
}

\author{
Regiana dos Santos MOURA ${ }^{1 *}$; Hans Raj GHEYI ${ }^{1}$; Everaldo Moreira da SILVA ${ }^{2}$; Elisson de \\ Araújo DIAS $^{1}$; Caliane Silva da CRUZ ${ }^{1}$; Mauricio Antônio COELHO FILHO ${ }^{3 *}$ \\ 1. Universidade Federal do Recôncavo da Bahia, Programa de Pós-Graduação em Engenharia Agrícola, Cruz das Almas, BA, Brasil. \\ regianna.ufpi@gmail.com*; 2. Universidade Federal do Piauí, Campus Professora Cinobelina Elvas, Bom Jesus, PI, Brasil. 3. Embrapa \\ Mandioca e Fruticultura, Cruz das Almas, BA, Brasil. mauricio-antonio.coelho@embrapa.br.
}

\begin{abstract}
The production of grafted passion fruit is an alternative for plant adaptation to saline environments. The objective of this study was to evaluate the effect of salt stress on physiology, biometry and fruit quality of $P$. edulis grafted on Passiflora spp. The experiment was conducted in completely randomized design, in a $3 \times 2$ factorial scheme, corresponding to three species of Passiflora (P. edulis, P. gibertii and $P$. cincinnata) with $P$. edulis scion and two levels of irrigation water salinity $\left(0.5\right.$ - control and $\left.4.5 \mathrm{dS} \mathrm{m}^{-1}\right)$, with four repetitions. Water salinity compromises gas exchanges $\left(\mathrm{CO}_{2}\right.$ assimilation raste and transpiration) and physiological variables (total chlorophyll and total water consumption) in grafted $P$. edulis. The interaction between the factors (water salinity $\mathrm{x}$ species) compromised only the growth in plant height and number of leaves. In relation to the species, auto-grafted $P$. edulis stood out from the other species, with higher internal $\mathrm{CO}_{2}$ concentration, number of leaves, stem dry mass, peel thickness, total soluble solids (TSS) of the pulp and TSS/TA ratio (titratable acidity). Auto-grafted $P$. edulis under saline conditions develops vital mechanisms (TSS and TSS/TA), which attenuates the effects of salt stress on the physico-chemical quality of the fruits.
\end{abstract}

KEYWORDS: Grafting. Passiflora cincinnata. Passiflora gibertii. Salinity. Gas exchanges.

\section{INTRODUCTION}

Brazil is the main producer of yellow passion fruit (Passiflora edulis Sims), with the Northeastern region and the state of Bahia producing $70 \%$ and $48.73 \%$, respectively, of the national production of 704 thousand tons (IBGE, 2018). Such production is attributed to its favorable edaphoclimatic conditions for the exploitation of the crop, with the exception of rainfall. Despite the significant production of yellow passion fruit, the Northeast region faces problems of soil salinization, especially under irrigated conditions, thus compromising the establishment of orchards. This is more evident in irrigated perimeters, due to inadequate irrigation management, associated with soil drainage problems and high evapotranspiration (BRITO et al., 2014; LEITE; GOMES; SANTOS, 2015; GADELHA et al., 2017).

Excess salts in water and/or in soil adversely affect the gas exchange, growth, yield and fruit quality, as they result in alteration in the physiological and biochemical functions of the plants, resulting in disturbances in water relations, changes in the absorption and use of essential nutrients, in addition to the accumulation of potentially toxic ions, especially $\mathrm{Na}^{+}$and $\mathrm{Cl}^{-}$
(NEVES et al., 2009; RIBEIRO et al., 2009; AMORIM et al., 2010). Regarding the water relations and gas exchange in plants under salt stress, there is a restriction in the availability of water due to the osmotic effect; consequently, stomatal closure limits stomatal conductance and transpiration, which reduces the rate of photosynthesis. It is known that the influx of $\mathrm{CO}_{2}$ is necessary through the stomata in the photosynthetic process, and water efflux also occurs through transpiration. Stomatal movement is the main mechanism of control of gas exchange in higher plants (SILVA et al., 2010).

In recent years, several studies have been carried out to evaluate the deleterious effects of salt stress on the yellow passion fruit crop (MONTAÑA, et al., 2014, FREIRE et al., 2014; MOURA et al., 2016a; SOUZA et al., 2016; MOURA et al., 2017), but these studies are limited to analyzing only the effect of irrigation with waters of different levels of salinity on plants produced by seeds in the phase of seedling formation. To date, there is no information in the literature on the behavior of auto- and interspecific-grafted passion fruit plants under salt stress conditions in the fruiting stage on fruit quality. 
Yellow passion fruit is traditionally grown through seeds; however, in order to minimize phytosanitary problems caused by soil pathogens, many researchers have studied the grafting of commercial species using rootstocks of wild species resistant to soil pathogens, mainly of the genus Fusarium (SANTOS et al., 2016; SCHMILDT et al., 2018), $P$. edulis/P. gibertii (CAVICHIOLI et al., 2011); P. edulis / P. mucronate (ALEXANDRE et al., 2013); P. edulis/P. mucronate (OLIARI et al., 2016); $P$. nitida/P. edulis, $P$. gibertii/P. edulis, $P$. alata - P. edulis (LIMA et al., 2017b).

However, most of these wild species have mechanisms of tolerance to water and salt stress because they are native to semi-arid regions. Thus, it is very opportune to study these species as rootstocks under conditions of salt stress for use in the agricultural sector. It is important to emphasize the desirable aspects in these plants after grafting, as these develop mechanisms to attenuate the effects of salt stress, such as stomatal regulation and compartmentalization of ions $\left(\mathrm{Na}^{+}\right.$and $\left.\mathrm{Cl}^{-}\right)$in the vacuoles, maintaining a favorable $\mathrm{K}^{+} / \mathrm{Na}^{+}$balance in the cytosol, allowing the development and production of the crop (SILVEIRA et al., 2016).

In this context, there is a need to adopt cultivation technologies that attenuate the deleterious effects of excess salts in irrigation water during the entire growth and production phase of the crop, especially with techniques that allow satisfactory agricultural production. The objective of this study was to evaluate the effect of salt stress on the physiology, biometry and fruit quality of $P$. edulis grafted on Passiflora spp.

\section{MATERIAL AND METHODS}

\section{Location of experiment}

The experiment was conducted in the experimental area of Embrapa Cassava and fruits, in Cruz das Almas, BA (Latitude of $12^{\circ} 48^{\prime} 19^{\prime \prime} \mathrm{S}$, Longitude of $39^{\circ} 06^{\prime} 23^{\prime \prime} \mathrm{W}$ and altitude of $225 \mathrm{~m}$ ), from March 2016 to August 2017, with mean annual rainfall, temperature and relative humidity of 1,224 $\mathrm{mm}, 24.5^{\circ} \mathrm{C}$ and $80 \%$, respectively (EMBRAPA, 2016).

\section{Experimental design and vegetative material}

The experiment was conducted in a completely randomized design, in a $3 \times 2$ factorial scheme, with three species of Passiflora (P. edulis, $P$. gibertii and $P$. cincinnata) and two levels of irrigation water salinity $(0.5$ - control and $4.5 \mathrm{dS} \mathrm{m}$ ${ }^{1}$ ), with four replicates each. The level of $0.5 \mathrm{dS} \mathrm{m}^{-1}$ corresponds to the local supply water and $4.5 \mathrm{dS} \mathrm{m}^{-1}$ was prepared by dissolving sodium chloride $(\mathrm{NaCl})$, using the relation between electrical conductivity $\left(\mathrm{dS} \mathrm{m}{ }^{-1}\right)$ and concentration of salts $\left(\mathrm{mg} \mathrm{L}^{-1}\right)$.

Initially, seeds of $P$. gibertii (BGP008), $P$. cincinnata (BGP290) and P. edulis (BRS 'Gigante Amarelo') were sown in polytubes in Vivato ${ }^{\circledR}$ substrate. After 90 days, when the plants had adequate height and stem diameter, they were grafted by the cleft method at the top. The scion used was $P$. edulis, BRS 'Gigante Amarelo' cultivar, in the three species mentioned above. After the grafting, the plants were transferred to a humid chamber for a period of seven days to avoid rapid dehydration of the scion and allow greater efficiency to obtain grafted seedlings (LIMA et al., 2017b).

\section{Experimental conditions}

The plants were transplanted into polyethylene bags with a capacity of $3 \mathrm{dm}^{3}$. The soil (sandy clay loam) used came from the experimental area of Embrapa Cassava and Fruits with the following physico-chemical characteristics in the 0 $20 \mathrm{~cm}$ layer: $\mathrm{pH}$ in water $=5.2 ; \mathrm{P}=2 \mathrm{mg} \mathrm{dm}^{-3} ; \mathrm{K}=$ $0.13 \mathrm{cmol}_{\mathrm{c}} \mathrm{dm}^{-3} ; \mathrm{Ca}=0.76 \mathrm{cmol}_{\mathrm{c}} \mathrm{dm}^{-3} ; \mathrm{Mg}=0.53$ $\mathrm{cmol}_{\mathrm{c}} \mathrm{dm}^{-3} ; \mathrm{Al}=0.3 \mathrm{cmol}_{\mathrm{c}} \mathrm{dm}^{-3} ; \mathrm{Na}=0.03 \mathrm{cmol}_{\mathrm{c}}$ $\mathrm{dm}^{-3} ; \mathrm{H}+\mathrm{Al}=3.19 \mathrm{cmol}_{\mathrm{c}} \mathrm{dm}^{-3} ; \mathrm{SB}=1.45 \mathrm{cmol}_{\mathrm{c}}$ $\mathrm{dm}^{-3} ; \mathrm{CEC}=4.64 \mathrm{cmol}_{\mathrm{c}} \mathrm{dm}^{-3} ; \mathrm{V}=31 \% ; \mathrm{OM}=8 \mathrm{~g}$ $\mathrm{kg}^{-1}$; total sand $=647 \mathrm{~g} \mathrm{~kg}^{-1}$; silt $=79 \mathrm{~g} \mathrm{~kg}^{-1}$; clay $=$ $274 \mathrm{~g} \mathrm{~kg}^{-1}$. After 30 days, the grafted plants were transplanted into $40 \mathrm{dm}^{3}$ containers with $40 \mathrm{~kg}$ of the above mentioned soil. $50 \mathrm{~g}$ of FTE BR12 $+50 \mathrm{~g}$ of MAP $+50 \mathrm{~g}$ of potassium chloride were added to each container, which were protected with plastic (mulch) in order to avoid losses of water by evaporation and kept in the experimental area of Embrapa Cassava and Fruits.

At 15 days after transplanting, the plants were submitted to irrigation with saline water according to treatments. Irrigations were carried out on alternate days, the volume of water applied being calculated according to the following formula: VI = (VA-VD)/0.9, where VI corresponds to the volume of water to be applied in the irrigation; VA to the volume of water applied in the previous irrigation; and VD to the volume of water drained in the previous irrigation. The index " 0.9 " corresponds to the factor that fixes the leaching fraction of $10 \%$, in order to avoid excessive accumulation of salts in the soil. Drainage control was performed in each irrigation, and a collector was attached to the base of each container. After 60 days of transplanting, fertilization was carried out with FORTH Soluveis ${ }^{\circledR}$ (Nitrogen 19\%, Phosphorus 19\%, Potassium 19\%, Boron $0.02 \%$, Magnesium 0.6\%), monthly, until 
completion of the experiment, applying in each event $1 \mathrm{~L} \mathrm{plant}^{-1}$ of the solution containing $4 \mathrm{~g} \mathrm{~L}^{-1}$.

The plants were conducted on vertical plain wire guides, located at $2.0 \mathrm{~m}$ above the soil surface. Pruning of the main branch was carried out when it passed $10 \mathrm{~cm}$ of the wire and the pruning of the two lateral branches was performed when both reached $1.5 \mathrm{~m}$ in length.

\section{Physiological characteristics}

At the beginning of flowering and fruiting (at 136 and 226 days after irrigation with saline water started, respectively), the plants were evaluated for $\mathrm{CO}_{2}$ assimilation rate $(A)$, transpiration (E), stomatal conductance (gs) and internal concentration of $\mathrm{CO}_{2}(\mathrm{Ci})$ in fully expanded leaves between 09:00 and 12:00h under saturated radiation and ambient conditions of temperature and $\mathrm{CO}_{2}$ concentration, utilizing a Infra-red Gas Analyser IRGA (LCI System, ADC, Hoddesdom). The total chlorophyll (TC) was measured in the beginning of flowering with digital chlorophyll meter, and total water consumption (TWC) was estimated at the end of the study by the difference between water volume applied and drained during the crop cycle.

\section{Biometric characteristics}

At 226 days after irrigation with saline water, passion fruit plants were evaluated for growth and development, by means of plant height $(\mathrm{PH})$ from the point of grafting, number of leaves (NL), stem diameter (SD), leaf dry mass (LDM), stem dry mass (SDM) and root dry mass (RDM) per plant.

\section{Physico-chemical characteristics of fruits}

At 226 days after irrigation with saline water, passion fruits were evaluated for fruit weight (FW), fruit length (FL), fruit diameter (FD), peel thickness (PT), peel weight (PW), weight of pulp (WP), total soluble solids (TSS), titratable acidity (TA) and the TSS/TA ratio, following the methodologies recommended by Jesus et al. (2017).

\section{Statistical analysis}

The data were submitted to analysis of variance (ANOVA) by the $F$ test $(p \leq 0.05)$ with further analysis of the interaction whenever it was significant. The quantitative factor, relative to the water salinity levels, and the species factor were analyzed by comparing means based on the Tukey test at 0.05 probability level. All analysis were performed using the Agricolae package implemented in the $\mathrm{R}$ program ( $\mathrm{R}$ DEVELOPMENT CORE TEAM, 2016).

\section{RESULTS AND DISCUSSION}

From the results of Table 1, it is observed that there was no interaction between the factors species x salinity, with a significant effect for the factor species only on the internal $\mathrm{CO}_{2}$ concentration $(\mathrm{Ci})$ in the flowering stage $(\mathrm{p}<0.05)$, while the factor salinity was significant for transpiration $(E)$ and photosynthesis $(A)$ in the flowering stage and $E$ in the fruiting stage, and total chlorophyll (TC) and total water consumption (TWC).

Table 1. Summary of $F$ test and means of gas exchange in passion fruit plants at 136 and 226 days after irrigation with saline water.

\begin{tabular}{|c|c|c|c|c|c|c|c|c|c|c|}
\hline \multirow{2}{*}{ SV } & \multicolumn{4}{|c|}{ Flowering (136 days) } & \multicolumn{4}{|c|}{ Fruiting (226 days) } & \multirow{2}{*}{$\mathrm{TC}$} & \multirow{2}{*}{ TWC } \\
\hline & $\mathrm{Ci}$ & $E$ & $g s$ & $A$ & $C \mathrm{i}$ & $E$ & $g s$ & $A$ & & \\
\hline Species (S) & * & $\mathrm{ns}$ & $\mathrm{ns}$ & $\mathrm{ns}$ & ns & $\mathrm{ns}$ & ns & ns & Ns & $\mathrm{ns}$ \\
\hline Water salinity (WS) & $\mathrm{ns}$ & $*$ & $\mathrm{~ns}$ & $*$ & ns & $*$ & ns & ns & * & ** \\
\hline Interaction (S x WS) & ns & $\mathrm{ns}$ & ns & ns & ns & $\mathrm{ns}$ & ns & ns & Ns & ns \\
\hline CV $(\%)$ & 10.42 & 25.07 & 20.4 & 21.19 & 25.23 & 20.27 & 1.65 & 22.54 & 28.52 & 9.52 \\
\hline \multicolumn{5}{|c|}{ P. edulis/Passiflora spp. } & \multicolumn{4}{|c|}{ Mean } & & \\
\hline P. cincinnata & $214.11 \mathrm{ab}$ & $1.93 \mathrm{a}$ & $0.11 \mathrm{a}$ & $8.60 \mathrm{a}$ & $185.93 \mathrm{a}$ & $1.73 \mathrm{a}$ & $0.08 \mathrm{a}$ & $5.47 \mathrm{a}$ & $45.33 \mathrm{a}$ & $88.44 a$ \\
\hline P. gibertii & $198.18 b$ & $1.77 \mathrm{a}$ & $0.10 \mathrm{a}$ & $8.42 \mathrm{a}$ & $226.41 \mathrm{a}$ & $1.96 \mathrm{a}$ & $0.08 \mathrm{a}$ & $5.91 \mathrm{a}$ & $41.62 \mathrm{a}$ & $85.37 \mathrm{a}$ \\
\hline P. edulis & $227.5 \mathrm{a}$ & $2.11 \mathrm{a}$ & $0.12 \mathrm{a}$ & $8.03 \mathrm{a}$ & $223.53 \mathrm{a}$ & $1.80 \mathrm{a}$ & $0.08 \mathrm{a}$ & $5.04 \mathrm{a}$ & $47.20 \mathrm{a}$ & $91.93 \mathrm{a}$ \\
\hline \multicolumn{11}{|c|}{ Water salinity $\left(\mathrm{dS} \mathrm{m}^{-1}\right)$} \\
\hline 0.5 & $216.90 \mathrm{a}$ & $2.18 \mathrm{a}$ & $0.12 \mathrm{a}$ & $9.13 \mathrm{a}$ & $223.37 \mathrm{a}$ & $2.0 \mathrm{a}$ & $0.10 \mathrm{a}$ & $5.80 \mathrm{a}$ & $50.36 \mathrm{a}$ & $100.15 \mathrm{a}$ \\
\hline 4.5 & $209.62 \mathrm{a}$ & $1.70 \mathrm{~b}$ & $0.10 \mathrm{a}$ & $7.57 \mathrm{~b}$ & $200.55 \mathrm{a}$ & $1.65 \mathrm{~b}$ & $0.07 \mathrm{a}$ & $5.17 \mathrm{a}$ & $39.07 \mathrm{~b}$ & $77.01 \mathrm{~b}$ \\
\hline
\end{tabular}

SV: source of variation. ns: not significant, * significant $(\mathrm{p} \leq 0.05)$ and $* *$ significant $(\mathrm{p} \leq 0.01)$ by the $\mathrm{F}$ test of the analysis of variance. Means followed by the same letter in the column do not differ by Tukey's test at 0.05 probability level. $C$ i: internal concentration of $\mathrm{CO}_{2}$ $\left(\mu \mathrm{mol} \mathrm{m} \mathrm{m}^{-2} \mathrm{~S}^{-1}\right)$; : transpiration $\left(\mathrm{mmol} \mathrm{H} \mathrm{H}_{2} \mathrm{O} \mathrm{m}^{-2} \mathrm{~s}^{-1}\right)$; gs: stomatal conductance $\left(\mathrm{mol} \mathrm{H}_{2} \mathrm{O} \mathrm{m}^{-2} \mathrm{~s}^{-1}\right) ; A: \mathrm{CO}_{2}$ assimilation rate $\left(\mu \mathrm{mol} \mathrm{m} \mathrm{s}^{-2} \mathrm{~s}^{-}\right.$ $\left.{ }^{1}\right)$; TC: total chlorophyll $\left(\mu \mathrm{mol} \mathrm{g} \mathrm{g}^{-1} \mathrm{FM}\right)$ and TWC: total water consumption $\left(\mathrm{L} \mathrm{plant}^{-1}\right)$. The gs data were transformed by the square root equation of $\mathrm{y}+1.0-\operatorname{SQRT}(\mathrm{y}+1.0)$. 
The variation of the internal concentration of $\mathrm{CO}_{2}(\mathrm{Ci})$ was intrinsic to the species factor in the flowering stage of the grafted passion fruit, as no influence was observed on $g s$ and $A$. Different values of $C i$ are observed in the different rootstocks, being higher in auto-grafted $P$. edulis, with 227.5 $\mu \mathrm{mol} \mathrm{mol}{ }^{-1}$ and lower in P. edulis /P. gibertii, with $198.18 \mu \mathrm{mol} \mathrm{mol}^{-1}$. In the fruiting stage there was no significant effect on $C$ i (Table 1), demonstrating that grafting exerts a pronounced effect on carbon metabolism in the flowering stage. Very high values of $\mathrm{Ci}$ in leaf mesophyll indicate that $\mathrm{CO}_{2}$ is not being used for sugar synthesis by photosynthetic process, with accumulation of this gas, indicating that other non-stomatal factors are interfering in this process (LARCHER, 2006). These values are in agreement with those found by Freire et al. (2014), who verified $C i$ values of $229.4 \mu \mathrm{mol} \mathrm{mol}^{-1}$ in $P$. edulis plants in the fruiting stage.

In different citrus rootstocks, Brito et al. (2016) also observed significant variations in the $C i$ of the plants, as observed in the present study, occurring different capacities of electron transport and gas exchange, to the detriment of the genetic variability observed in the species studied.

In the flowering stage of the grafted plants, the water salinity of $4.5 \mathrm{dS} \mathrm{m}^{-1}$ affected the transpiration rate of plants $\left(1.7 \mathrm{mmol} \mathrm{H}_{2} \mathrm{O} \mathrm{m}^{-2} \mathrm{~s}^{-1}\right)$, $22 \%$ less compared to the control $\left(2.18 \mathrm{mmol} \mathrm{H}_{2} \mathrm{O}\right.$ $\mathrm{m}^{-2} \mathrm{~s}^{-1}$ ) (Table 1), and this reduction in transpiration is a consequence of the effect of the salts on plant physiology (DIAS et al., 2016). Reduction in transpiration induced by water and salt stresses were also observed in Jatropha curcas by Silva et al. (2010), in P. edulis by Freire et al. (2014) and in Ricinus communis L. by Lima et al. (2017a). Leaf transpiration under conditions of salt stress is generally attributed to the partial closure of the stomata associated with the osmotic effect and ionic toxicity on plant metabolism (NEVES et al., 2009). Under these conditions, there is an imbalance between water absorption by the roots and the transpiration; therefore, partial closure of stomata is considered a strategy to avoid excessive dehydration or a consequence of the water imbalance in the epidermis of the leaves (RIBEIRO et al., 2009).

The net assimilation rate (A) was compromised when the plants were irrigated with saline water (Table 1) in the flowering stage, being a sensitive phase (136 days after irrigation with saline water), with lower values $\left(7.57 \mu \mathrm{mol} \mathrm{CO}_{2} \mathrm{~m}^{2} \mathrm{~s}^{-1}\right)$, whereas the plants under control treatment reached $9.13 \mu \mathrm{mol} \mathrm{CO} \mathrm{Cm}^{2} \mathrm{~s}^{-1}$, with a $17.1 \%$ reduction. Salt stress reduces the net $\mathrm{CO}_{2}$ assimilation and transpiration rate in glycophytes (FREIRE et al.,
2014), corroborating the responses obtained in the rate of net assimilation and transpiration in the flowering and fruiting stages (Table 1). Bezerra et al. (2018), evaluating Psidium guajava under salt stress, also observed a reduction of $18.35 \%$ per unit increase of ECW.

Salinity causes great disturbances in plant metabolism, and the first effects caused by excess salt are biophysical in nature, especially osmotic effects, restricting water transport, then quickly triggering a sequence of hormone-modulated reactions, which leads to reduced water absorption, transpiration and restriction of photosynthetic $\mathrm{CO}_{2}$ assimilation in cells, among others. In the present study, ECw of $4.5 \mathrm{dS} \mathrm{m}^{-1}$ reduced the $A$ by $17 \%$, due to osmotic effects on plant metabolism (SILVEIRA et al., 2016), indicating that some nonstomatal factor is interfering in this process.

Physiological disturbances in glycophytes caused by salt stress were verified by Cha-um and Kirdmanee (2011) and Freire et al. (2014), corroborating the results observed in passion fruit plants irrigated with saline water. The use of saline water in Vigna unguiculata and Sorghum bicolor also reduced the photosynthetic rate, as observed in the present study, attributed to the partial closure of the stomata (NEVES et al., 2009; SILVA et al., 2013; COELHO et al., 2018). Prolonged exposure to salts causes changes in the stomatal conductance of the plant, thereby limiting the influx of $\mathrm{CO}_{2}$ into the mesophyll. In addition, high concentrations of ions have been reported as the cause of damage to enzyme and cell membrane structures, directly affecting photosynthesis (SILVA et al., 2011).

In the fruiting stage, the passion fruit plants under salt stress had reduced transpiration (1.65 mmol $\mathrm{H}_{2} \mathrm{O} \mathrm{m} \mathrm{m}^{-2} \mathrm{~s}^{-1}$ ), with inhibition of $17.5 \%$ compared to the control, a result similar to that found in the flowering stage and in the rate of assimilation $(A)$ (Table 1).

These results agree with those of Bezerra et al. (2018), who observed reductions in transpiration at 255 and 300 days after transplanting of Psidium guajava equal to 14.80 and $3.62 \%$ per unit increase in irrigation water salinity, respectively. The increment in soil salinity caused by the increase in irrigation water salinity reduces the osmotic potential of the soil solution, requiring from plants greater expenditure of energy to absorb water. In this situation, in an attempt to reduce water losses by transpiration, the plants decrease or deactivate part of their leaf area, hence reducing net photosynthesis and metabolic production (Freire et al., 2014). 
Likewise, Nascimento et al. (2016) observed in vines under water deficit, reduction in photosynthesis, stomatal conductance and transpiration, while Suassuna et al. (2014) verified reductions in $g s$ and $E$ in citrus rootstocks with water restriction. One of the effects of salt stress is the reduction in the availability of water to plants, which causes significant decreases in photosynthetic activity, transpiration and stomatal conductance, and this condition is mainly related to stomatal closure. Neves et al. (2009) and Silva et al. (2013), studying cowpea and Coelho et al. (2018) studying sorghum, also found that salt stress negatively affected plant transpiration. The observed reduction in transpiration rate with the increase in water salinity was due to the osmotic effect of salts around the roots and the possible accumulation of potentially toxic ions $\left(\mathrm{Na}^{+}\right.$and $\left.\mathrm{Cl}^{-}\right)$in leaf tissues (BEZERRA et al., 2018).

The ECw of $4.5 \mathrm{dS} \mathrm{m}^{-1}$ affected total chlorophyll (TC) and total water consumption (TWC) with reductions of 22.4 and $23.1 \%$ compared to the low-salinity treatment $(\mathrm{ECW}=0.5$ $\mathrm{dS} \mathrm{m}^{-1}$ ), respectively (Table 1 ). This reduction in chlorophyll content is probably due to the effect of accumulated ions on chlorophyll biosynthesis in different fractions. The reduction in chlorophyll biosynthesis may be an acclimation response to salt stress in the context of energy savings and lower light energy uptake to avoid photooxidative stress (SILVEIRA et al., 2016). According to Munns and Tester (2008), the reduction in chlorophyll content is the result of imbalance in physiological and biochemical activities promoted by the salt content in addition to that tolerated by crops. For these authors, the excess of salt stimulates the enzymatic activity of chlorophyllase, which degrades the photosynthesizing pigment molecules and induces the structural destruction of chloroplasts, also causing the imbalance and loss of activity of pigmentation proteins.

The reduction of the total water consumption in the saline treatment is attributed to the high salt concentration of the irrigation water, which reduces the water potential of the soil solution, causing a decrease in the water availability to the plant, thus reducing water consumption (DIAS et al., 2016), and consequently reducing transpiration and photosynthesis (Table 1). Similar results were also observed in Passiflora edulis by Freire et al. (2014), who found a $42.2 \%$ reduction in net photosynthesis between plants irrigated with low-salinity water and $4.5 \mathrm{dS} \mathrm{m}^{-1}$, and Moura et al. (2017) observed a reduction of $4.48 \%$ in total water consumption per unit increase in irrigation water electrical conductivity $(\mathrm{ECw})$, due to high salinity in irrigation water.

There was a significant effect of the factor species on NL $(p<0.05)$ and LDM $(p<0.01)$. However, salinity did not have a significant effect on any of the biometric variables evaluated, while species $\mathrm{x}$ salinity interaction for the NL and $\mathrm{PH}$ variables was significant at 0.05 probability level (Table 2).

Table 2. Summary of $\mathrm{F}$ test and means of the biometric variables of $P$. edulis grafted on three rootstocks of Passiflora spp. at 226 days after irrigation with saline water.

\begin{tabular}{lllllll}
\hline SV & PH $(\mathrm{cm})$ & SD $(\mathrm{mm})$ & NL & LDM $(g)$ & SDM $(\mathrm{g})$ & RDM $(\mathrm{g})$ \\
\hline Species (S) & $\mathrm{ns}$ & $\mathrm{ns}$ & $*$ & $\mathrm{~ns}$ & $* *$ & $\mathrm{~ns}$ \\
Water salinity (WS) & $\mathrm{ns}$ & $\mathrm{ns}$ & $\mathrm{ns}$ & $\mathrm{ns}$ & $\mathrm{ns}$ & $\mathrm{ns}$ \\
Interaction (S x WS) & $*$ & $\mathrm{~ns}$ & $*$ & $\mathrm{~ns}$ & $\mathrm{~ns}$ & $\mathrm{~ns}$ \\
CV $(\%)$ & 27.35 & 15.82 & 17.71 & 10.57 & 14.57 & 13.36 \\
\hline$P$. edulis/Passiflora spp. & & \multicolumn{5}{c}{ Mean } \\
\hline P. cincinnata & $81.00 \mathrm{a}$ & $6.75 \mathrm{a}$ & $13.37 \mathrm{c}$ & $4.86 \mathrm{a}$ & $2.36 \mathrm{ab}$ & $1.47 \mathrm{a}$ \\
$P$. gibertii & $107.83 \mathrm{a}$ & $5.61 \mathrm{a}$ & $18.03 \mathrm{~b}$ & $5.04 \mathrm{a}$ & $2.05 \mathrm{~b}$ & $1.43 \mathrm{a}$ \\
$P$. edulis & $90.83 \mathrm{a}$ & $6.80 \mathrm{a}$ & $18.66 \mathrm{a}$ & $5.05 \mathrm{a}$ & $2.77 \mathrm{a}$ & $1.47 \mathrm{a}$ \\
\hline Water salinity $\left(\mathrm{dS} \mathrm{m}^{-1}\right)$ & & & & & & \\
\hline 0.5 & $99.25 \mathrm{a}$ & $6.74 \mathrm{a}$ & $17.19 \mathrm{a}$ & $5.15 \mathrm{a}$ & $2.49 \mathrm{a}$ & $1.50 \mathrm{a}$ \\
4.5 & $87.20 \mathrm{a}$ & $6.03 \mathrm{a}$ & $16.19 \mathrm{a}$ & $4.80 \mathrm{a}$ & $2.30 \mathrm{a}$ & $1.42 \mathrm{a}$ \\
\hline
\end{tabular}

$\mathrm{SV}$ : source of variation; ns: not significant, ${ }^{*}$ significant $(\mathrm{p} \leq 0.05)$ and $* *$ significant $(\mathrm{p} \leq 0.01)$ by the test $\mathrm{F}$. Means followed by the same letter in the column do not differ by Tukey test at 0.05 probability level. PH: plant height, SD: stem diameter, NL: number of leaves, LDM: leaf dry mass, SDM: stem dry mass and RDM: root dry mass.

For the interaction between species and water salinity, with regard to plant height, $P$. edulis/P. edulis had higher $\mathrm{PH}$ in the saline treatment $\left(4.5 \mathrm{dS} \mathrm{m}^{-1}\right)$, with $45.5 \%$ superiority compared to the low-salinity treatment. However, the $P$. edulis plants grafted on $P$. cincinnata and $P$. gibertii in the saline treatment had reductions of 
40.78 and $23.22 \%$, respectively, in the height compared to the non-saline treatment (Figure 1A)

The reduction of $\mathrm{PH}$ as a function of the increase in salt concentration occurred due to the osmotic effect, which restricted the availability of water and nutrients, consequently compromising the physiological and metabolic processes for plants to adjust and produce vital substances, such as proteins, enzymes, nucleic acids and other organic assimilates, such as carbohydrates and sugars, essential for osmotic adjustment and growth (HEIDARI, 2009). This result corroborates the physiological and gas exchange results, where TWC, TC, $E$ and $A$ were compromised under highsalinity water (Table 1 ).

In relation to the species, $P$. edulis in the saline treatment indicated superiority in comparison to the others, and in the control treatment it had lower height. It is suggested that stress in

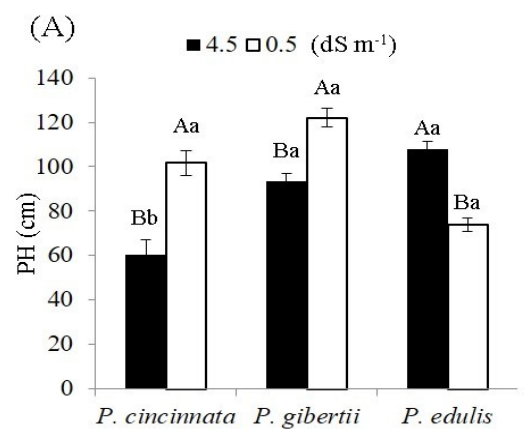

autografted plants of $P$. edulis activates mechanisms that minimize the effects of excess salts on the vital processes of plants, leading to higher $\mathrm{PH}$ in the saline treatment. This result shows that grafting is a valid strategy to avoid, at least partially, the ionic stress. Estañ et al. (2005) suggested that the effect of salt stress on tomato rootstock may vary according to the level of stress. These authors observed that Radja and Pera rootstocks had better physiological responses at higher salinity levels $(50$ and $75 \mathrm{mM}$ $\mathrm{NaCl}$ ); likewise, the autografted $P$. edulis in the present study had greater growth under salt stress. Moura et al. (2017) and Andrade et al. (2018) verified that $P$. edulis was significantly affected by reduction in $\mathrm{PH}$ with increased water salinity, while Souza et al. (2016) observed that the height of $P$. edulis under $\mathrm{ECw}$ of $4.0 \mathrm{dS} \mathrm{m}^{-1}$ was not affected in sandy soil, that is, this species has mechanisms of tolerance to salinity.

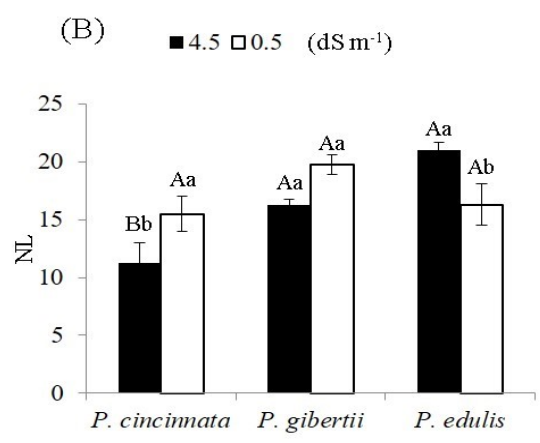

Figure 1. A: Plant height (PH); B: number of leaves (NL) of P. edulis grafted on three rootstocks of Passiflora spp. submitted to salt stress at 226 days after irrigation with saline water.

Means followed by lowercase letters (species) for the same water salinity levels and uppercase lettrers (salinity) for the same species do not differ by Tukey's test $(\mathrm{p} \leq 0.05)$.

In relation to the factor species, autografted $P$. edulis had the highest number of leaves, followed by $P$. gibertii rootstock with 39.56 and $34.85 \%$ of superiority in comparison to $P$. cincinnata, respectively (Table 2), and this result for $P$. edulis is in agreement with the $C i$ observed in Table 1.

Salts decrease the absorption of water and nutrients by plants and, when under salt stress, trigger the osmotic adjustment mechanism to maintain the turgidity of the cells, which results in a slower growth of the stressed plants (DEINLEIN et al., 2014, GUERZONI et al., 2014). For the species $\mathrm{x}$ water salinity interaction, there was a reduction in leaf production in $P$. edulis/P. cincinnata plants, when they were submitted to ECW of $4.5 \mathrm{dS} \mathrm{m}^{-1}$, decreasing the NL by $27.41 \%$ in comparison to the non-saline treatment $\left(\mathrm{ECw}=0.5 \mathrm{dS} \mathrm{m}^{-1}\right)$. Therefore, lower NL was observed in relation to the other combinations of grafting (Figure 1B). In autografted plants of $P$. edulis, an opposite effect was observed, with an increase of $28.67 \%$ in the NL under highsalinity $\left(4.5 \mathrm{dS} \mathrm{m}^{-1}\right)$; however, when using $P$. gibertii as rootstock, no significant changes were observed at 0.05 probability level (Figure 1B).

Autografted $P$. edulis induced higher leaf production under conditions of high salinity, as verified in PH (Figure 1A), and grafting in this species attenuated the effect of the salts, being an alternative for passion fruit cultivation with saline water. In salinity studies with Passiflora, Moura et al. (2016a) found that $P$. edulis and $P$. gibertii are tolerant to salinity up to $4.7 \mathrm{dS} \mathrm{m} \mathrm{m}^{-1}$ and $P$. cincinnata is moderately tolerant, corroborating the results of the present study. However, it is important to point out that the plant may exhibit a higher number of leaves and even have a smaller total leaf area due to salt stress. 
The dry mass of the stem in the combination $P$. edulis/P. edulis was on average $35.12 \%$ higher compared to $P$. edulis/P. gibertii (Table 2), confirming the results of $C i$ and NL for the autografted plants of $P$. edulis. This response can be justified by the different morpho-anatomical characteristics of the species, which may have incompatibility between the xylem and phloem tissues when grafting is performed or due to the smaller diameter of the stem identified in this species, which may have influenced the dry mass of the stem of the scion (LIMA et al., 2017a). In addition, the grafting point may have affected the flow of hormones and other chemical compounds between rootstock and scion.

Marè, Mica and Cattivelli (2016) observed in autografted vines and different rootstocks that plants retain their genetic identity, but some transcription factors, mRNAs, microRNAs, RNAs, peptides, and proteins are mobile in their vascular system and can pass through the graft union; further, it is suggested that cells at the interface of the graft can induce an immune response as an effect due to the presence of a graft belonging to other species, corroborating results obtained in the present study for the $P$. gibertii rootstock.

Table 3 shows the significance of the $F$ test and the means of the physico-chemical attributes of the fruit quality. The species had a significant effect only on peel thickness (PT), total soluble solids (TSS) and ratio of total soluble solids to titratable acidity $(\mathrm{TSS} / \mathrm{TA})(\mathrm{p}<0.05)$. There was no single effect for salinity and interaction between the two studied factors.

Table 3. Summary of $\mathrm{F}$ test and means for fruit quality of $P$. edulis grafted on Passiflora spp. subjected to salt stress

\begin{tabular}{llllllllll}
\hline SV & FW & FL & FD & PT & PW & WP & TSS & TA & TSS/TA \\
\hline Species (S) & $\mathrm{ns}$ & $\mathrm{ns}$ & $\mathrm{ns}$ & $*$ & $\mathrm{~ns}$ & $\mathrm{~ns}$ & $*$ & $\mathrm{~ns}$ & $*$ \\
Water salinity (WS) & $\mathrm{ns}$ & $\mathrm{ns}$ & $\mathrm{ns}$ & $\mathrm{ns}$ & $\mathrm{ns}$ & $\mathrm{ns}$ & $\mathrm{ns}$ & $\mathrm{ns}$ & $\mathrm{ns}$ \\
Interaction (S x WS) & $\mathrm{ns}$ & $\mathrm{ns}$ & $\mathrm{ns}$ & $\mathrm{ns}$ & $\mathrm{ns}$ & $\mathrm{ns}$ & $\mathrm{ns}$ & $\mathrm{ns}$ & $\mathrm{ns}$ \\
CV (\%) & 33.67 & 11.37 & 9.85 & 15.33 & 41.19 & 32.43 & 16.00 & 16.34 & 18.98 \\
\hline P. edulis/Passiflora spp. & & & \multicolumn{7}{c}{ Mean } \\
\hline P. cincinnata & $138.16 \mathrm{a}$ & $79.93 \mathrm{a}$ & $71.1 \mathrm{a}$ & $7.03 \mathrm{~b}$ & $74.08 \mathrm{a}$ & $62.12 \mathrm{a}$ & $10.93 \mathrm{~b}$ & $3.15 \mathrm{a}$ & $3.68 \mathrm{~b}$ \\
P. gibertii & $137.53 \mathrm{a}$ & $81.02 \mathrm{a}$ & $68.02 \mathrm{a}$ & $7.06 \mathrm{~b}$ & $68.66 \mathrm{a}$ & $69.32 \mathrm{a}$ & $12.06 \mathrm{ab}$ & $3.27 \mathrm{a}$ & $3.76 \mathrm{~b}$ \\
P. edulis & $137.45 \mathrm{a}$ & $84.67 \mathrm{a}$ & $70.13 \mathrm{a}$ & $8.55 \mathrm{a}$ & $75.21 \mathrm{a}$ & $65.68 \mathrm{a}$ & $13.56 \mathrm{a}$ & $2.97 \mathrm{a}$ & $4.65 \mathrm{a}$ \\
\hline Water salinity $\left(\mathrm{dS} \mathrm{m}^{-1}\right)$ & & & & & & & & & \\
\hline 0,5 & $146.24 \mathrm{a}$ & $85.45 \mathrm{a}$ & $71,80 \mathrm{a}$ & $7.75 \mathrm{a}$ & $77.28 \mathrm{a}$ & $70.02 \mathrm{a}$ & $12.79 \mathrm{a}$ & $3.20 \mathrm{a}$ & $4.20 \mathrm{a}$ \\
4,5 & $129.19 \mathrm{a}$ & $78.30 \mathrm{a}$ & $67.70 \mathrm{a}$ & $7.35 \mathrm{a}$ & $68.02 \mathrm{a}$ & $61.40 \mathrm{a}$ & $11.58 \mathrm{a}$ & $3.06 \mathrm{a}$ & $3.86 \mathrm{a}$ \\
\hline
\end{tabular}

SV: source of variation; ns: not significant and ${ }^{*}$ significant $(\mathrm{p} \leq 0.05)$ by the $\mathrm{F}$ test of the analysis of variance. Means followed by the same letter in the column do not differ by Tukey's test at 0.05 probability level. FW: fruit weight - g; FL: fruit length - cm; FD: fruit diameter - mm; PT: peel thickness - mm; PW: peel weight - g; WP: weight of the pulp - g; TSS: total soluble solids - ${ }^{\circ}$ Brix; TA: titratable acidity - $\%$ and TSS/TA: ratio of total soluble solids to titratable acidity.

The peel thickness of the autografted $P$. edulis was higher $(8.55 \mathrm{~mm})$ when compared to the other grafting combinations (Table 3). However, this result is lower than that found by Nascimento et al. (2015) which was $9.25 \mathrm{~mm}$. The values of the $P$. cincinnata and $P$. gibertii rootstocks are similar to those obtained by Freire et al. (2010) $(7.11 \mathrm{~mm})$ in fruits of plants irrigated with saline water $(4.5 \mathrm{dS}$ $\left.\mathrm{m}^{-1}\right)$. Fruits of yellow passion fruit with lower peel thickness have a higher proportion of pulp (NASCIMENTO et al., 2015). However, the results presented here did not differ for the pulp mass as a function of the salinity and the rootstock used (Table 3).

Autografted $P$. edulis had the highest value of total soluble solids of fruits (13.56 $\left.{ }^{\circ} \mathrm{Brix}\right)$, followed by $P$. gibertii rootstock (12.06 ${ }^{\circ}$ Brix), while $P$. cincinnata showed the lowest value (10.39
${ }^{\circ}$ Brix). Nascimento et al. (2015) obtained maximum values of 12.78 and $11.29^{\circ} \mathrm{Brix}$ in treatments with and without the use of biofertilizer + NPK, while Freire et al. (2010) and Dias et al. (2011), working with biofertilizer and irrigation with saline water $\left(4.5 \mathrm{dS} \mathrm{m}^{-1}\right)$, obtained fruits with values of 10.26 and $12.1{ }^{\circ}$ Brix, respectively. However, no difference was observed between high and low salinity treatments in the present research, suggesting that the grafting technique may have had a positive influence on the quality of the fruits, reducing the deleterious effects of the salts on fruit quality, since they were not influenced by salinity.

The TSS values for autografting of $P$. edulis and $P$. gibertii rootstock are within the quality standards, in which the technical regulation for the establishment of the Identity and Quality Standards (IQS) for pulp of passion fruit of the Ministry of 
Agriculture establishes the minimum value of 11 ${ }^{\circ}$ Brix for the soluble solids content (RAIMUNDO et al., 2009). On the other hand, the mean value of TSS in the $P$. cincinnata rootstock is not suitable for pulp production (10.39 ${ }^{\circ}$ Brix). Morais (2017) in the evaluation of fruits of the same species found values ranging from 9.07 to $11.90^{\circ} \mathrm{Brix}$. This low value of ${ }^{\circ} \mathrm{Brix}$ is perhaps directly related to the genetic characteristics of the species in interaction with the scion.

Autografted $P$. edulis showed a higher TSS/TA ratio, corroborating the characteristics of PT and TSS (Table 3) and also in the $C$ i (Table 1) and NL and SDM growth variables (Table 2). Moura et al. (2016b) found TSS/TA of 6.65 and 5.55 in $P$. edulis submitted to different doses of nitrogen, values higher than that found in the present study, but this superiority may be attributed to nitrogen fertilization. On the other hand, the values of TSS/TA indicate the palatability of the fruits because the balance between acids and sugars is more representative than the individual evaluation of these parameters (BRITO NETO et al., 2011).

In general, the salinity of the water affected only the gas exchange (rate of $\mathrm{CO}_{2}$ assimilation and transpiration) and physiological variables (total chlorophyll and total water consumption), since the interaction between the factors (water salinity $x$ species) only affected the growth in plant height and number of leaves. In relation to the species, autografted $P$. edulis stood out from the other species, with higher internal $\mathrm{CO}_{2}$ concentration, number of leaves, stem dry mass, fruit peel thickness, total soluble solids of the pulp and TSS/TA ratio.

\section{CONCLUSIONS}

The salinity of the irrigation water compromises the gas exchange (rate of $\mathrm{CO}_{2}$ assimilation and transpiration) and physiological variables (total chlorophyll and total water consumption) in grafted $P$. edulis.

The interaction between the factors (water salinity $\mathrm{x}$ species) only affects the growth in plant height and number of leaves.

In relation to the species, autografted $P$. edulis stood out from the others, showing higher internal $\mathrm{CO}_{2}$ concentration, number of leaves, stem dry mass, fruit peel thickness, total soluble solids of the pulp and TSS/TA ratio.

The autografted $P$. edulis under salt stress conditions develops vital mechanisms (TSS and TSS/TA), which attenuate the effects of salinity on the physico-chemical quality of the fruits.

\section{ACKNOWLEDGMENTS}

To the Coordination for the Improvement of Higher Education Personnel (CAPES), to the National Council for Scientific and Technological Development (CNPq) for granting scholarships to the authors, to the Post Graduate Program in Agricultural Engineering of the Universidade Federal do Recôncavo da Bahia and Embrapa Cassava and Fruits of Cruz das Almas - BA, for providing the infrastructure facilities to conduct the experiment.

RESUMO: A produção de maracujazeiro enxertado é uma alternativa para adaptação das plantas a ambientes salinos. Objetivou-se avaliar o efeito do estresse salino na fisiologia, biometria e qualidade de frutos de $P$. edulis enxertado em espécies de Passiflora spp. O delineamento utilizado foi inteiramente casualizado, em esquema fatorial $3 \times 2$, sendo três espécies de Passiflora ( $P$. edulis, $P$. gibertii e $P$. cincinnata) tendo como copa $P$. edulis e dois níveis de salinidade de água de irrigação $\left(0,5\right.$ - testemunha e $\left.4,5 \mathrm{dS} \mathrm{m}^{-1}\right)$, com quatro repetições. A salinidade da água compromete as trocas gasosas (taxa de assimilação de $\mathrm{CO}_{2}$ e transpiração) e variáveis fisiológicas (clorofila total e consumo hídrico total) em $P$. edulis enxertado. A interação entre os fatores (salinidade da água $\mathrm{x}$ espécie) compromete apenas o crescimento em altura de plantas e número de folhas. Em relação às espécies, o $P$. edulis auto enxertado se destaca em relação as demais espécies apresentando maior concentração interna de $\mathrm{CO}_{2}$, número de folhas, massa seca de caule, espessura da casca do fruto, sólidos solúveis totais (SST) da polpa e razão sólidos solúveis totais por acidez titulável (SST/AT). O $P$. edulis auto enxertado sob condições de salinidade, desenvolve mecanismos vitais (SST e SST/AT), que atenuam os efeitos do estresse salino na qualidade físico-química dos frutos.

PALAVRAS-CHAVE: Enxertia. Passiflora cincinnata. Passiflora gibertii. Salinidade. Trocas gasosas. 


\section{REFERENCES}

ALEXANDRE, R. S.; LOPES, J. C.; TIRADENTES, A. T.; BRUCKNER, C. H.; OTONI, W. C. Metodologia de minienxertia em maracujazeiro. Revista Brasileira de Fruticultura, Jabuticabal, v. 35, n. 1, p. 329-332, Nov. 2013. https://doi.org/10.1590/S0100-29452013000100040

AMORIM, A. F.; GOMES FILHO, E.; BEZERRA, M. A.; PRISCO, J. T.; LACERDA, C. F. Respostas fisiológicas de plantas adultas de cajueiro anão precoce à salinidade. Revista Ciência Agronômica, Fortaleza, v. 41, n. 1, p. 113-121, Mar. 2010.

ANDRADE, J. R.; MEDEIROS, A. S.; MAIA JÚNIOR, S. O.; REZENDE, L. P.; ARAÚJO NETO, J. C. Germination and morphophysiology of Passion fruit seedlings under salt water irrigation. Pesquisa Agropecuária Tropical, Goiânia, v. 48, n. 3, p. 229-236, Dez. 2018. https://doi.org/10.1590/198340632018v4852710

BEZERRA, I. L.; NOBRE, R. G.; GHEYI, H. R.; LIMA, G. S.; BARBOSA. J. L. Physiological indices and growth of 'Paluma' guava under saline water irrigation and nitrogen fertigation. Revista Caatinga, Mossoró, v. 31, n. 4, p. 808 - 816, Jan. 2018. https://doi.org/10.1590/1983-21252018v31n402rc

BRITO NETO, J. F.; PEREIRA, W. E.; CAVALCANTE, L. F.; ARAÚJO, R. C.; LACERDA, J. S. Produtividade e qualidade de frutos de mamoeiro 'Sunrise Solo' em função de doses de nitrogênio e boro. Semina: Ciências Agrária, Londrina, v. 32, n. 1, p. 69-80, Jan. 2011. https://doi.org/10.5433/16790359.2011v32n1p69

BRITO, M. E. B.; FERNANDES, P. D.; GHEYI, H. R.; MELO, A. S.; SOARES FILHO, W. S.; SANTOS, R. T. Sensibilidade à salinidade de híbridos trifoliados e outros porta-enxertos de citros. Revista Caatinga, Mossoró, v. 27, n. 1, p. 17-27, Mar. 2014.

BRITO, M. E. B.; SÁ, F. V. S.; SILVA, L. A.; MOREIRA, R. C. L.; PEREIRA, F. H. F.; SOARES FILHO, W. S. Crescimento e trocas gasosas de porta-enxertos de citros em sistema hidropônico alternativo. Irriga, Botucatu, Edição Especial, p. 166-180, Fev. 2016. https://doi.org/10.15809/irriga.2016v1n1p166-180

CAVICHIOLI, J. C.; CORRÊA, L. de S.; GARCIA, M. J. de M.; FISCHER, I. H. Desenvolvimento, produtividade e sobrevivência de maracujazeiro-amarelo enxertado e cultivado em área com histórico de morte prematura de plantas. Revista Brasileira de Fruticultura, Jaboticabal, v. 33, n. 2, p. 567-574, Jun. 2011. https://doi.org/10.1590/S0100-29452011005000075

CHA-UM, S.; KIRDMANEE, C. Remediation of salt-affected soil by the addition of organic matter: an investigation into improving glutinous rice productivity. Scientia Agricola, Piracicaba, v. 68, n. 4, p. 406-410, Jul. 2011. https://doi.org/10.1590/S0103-90162011000400003

COELHO, D. S.; SIMÕES, W. L.; SALVIANO, A. M.; MESQUITA, A. C.; ALBERTO, K. C. Gas exchange and organic solutes in forage sorghum genotypes grown under different salinity levels. Revista Brasileira de Engenharia Agrícola e Ambiental, Campina Grande, v. 22, n. 4, p. 231-236, Fev. 2018. https://doi.org/10.1590/1807-1929/agriambi.v22n4p231-236

DEINLEIN U.; STEPHAN A. B.; HORIE, T. LUO. W, XU. G.; SCHROEDER J. I. Plant salt-tolerance mechanisms, Trends in Plant Science, v. 6, p. 371-379, Jun. 2014.

https://doi.org/10.1016/j.tplants.2014.02.001

DIAS, N. S.; BLANCO, F. F.; SOUZA, E. R.; FERREIRA, J. F. S.; SOUSA NETO, O. N.; QUEIROZ, Í. S. R., Efeitos dos sais no solo e na planta. In: GHEYI, H. R.; DIAS, N. S.; LACERDA, C. F; GOMES FILHO, E. (ed.). Manejo da salinidade na agricultura: estudos básicos e aplicados. 2.ed. Fortaleza: INCTSal. 2016. p. 151-161. 
DIAS, T. J.; CAVALCANTE, L. F.; LEON, M. J.; SANTOS, G. P.; ALBUQUERQUE, R. P. F. Produção do maracujazeiro e resistência mecânica do solo com biofertilizante sob irrigação com águas salinas. Revista Ciência Agronômica, Fortaleza, v. 42, n. 3, p. 644-651, Jul. 2011. https://doi.org/10.1590/S180666902011000300010

EMBRAPA - Empresa Brasileira de Pesquisa Agropecuária. Boletim meteorológico da estação convencional de Cruz das Almas, BA: variabilidade e tendências climáticas. Silva, T. S. M., Coelho Filho, M. A., Coelho, E. F. - [recurso eletrônico] - Cruz das Almas: Embrapa Mandioca e Fruticultura. 2016. Disponivel em: https://www.researchgate.net/publication/305789702_Boletim_meteorologico_da_estacao_convencional_de_C ruz_das_Almas_BA_variabilidade_e_tendencias_climaticas. Acesso em 05 Nov. 2018.

ESTAÑ, M. T.; MARTINEZ-RODRIGUEZ, M. M.; PEREZ-ALFOCEA, F.; FLOWERS, T. J.; BOLARIN, M. C. Grafting raises the salt tolerance of tomato through limiting the transport of sodium and chloride to the shoot. Journal of Experimental Botany, Lancaster, v. 56, n. 412, p. 703-712, Fev. 2005.

https://doi.org/10.1093/jxb/eri027

FREIRE, J. L. O.; CAVALCANTE, L. F. ; REBEQUI, A. M.; DIAS, T. J.; NUNES, J. C.;CAVALCANTE, I. H. L. Atributos qualitativos do maracujá amarelo produzido com água salina, biofertilizante e cobertura morta no solo. Revista Brasileira de Ciências Agrárias, Recife, v. 5, n. 1, p.102-110, Jan. 2010.

https://doi.org/10.5039/agraria.v5i1a674

FREIRE, J. L. O.; DIAS, T. J.; CAVALCANTE, L, F.; FERNANDES, P. D.; LIMA NETO, A. J. Rendimento quântico e trocas gasosas em maracujazeiro amarelo sob salinidade hídrica, biofertilização e cobertura morta.. Revista Ciência Agronômica, Fortaleza, v. 45, n. 1, p. 82-91, Jan. 2014. https://doi.org/10.1590/S180666902014000100011

GADELHA, C. G.; MIRANDA, R. S.; ALENCAR, N. L. M.; COSTA, J. H.; PRISCO, J. T.; GOMES-FILHO, E. Exogenous nitric oxide improves salt tolerance during establishment of Jatropha curcas seedlings by ameliorating oxidative damage and toxic ion accumulation. Journal of Plant Physiology, Melbourne, v. 212, n. 1, p. 69-79, Fev. 2017. https://doi.org/10.1016/j.jplph.2017.02.005

GUERZONI, J. T. S.; BELINTANI, N. G.; MOREIRA, R. M. P.; HOSHINO, A. A.; DOMINGUES, D. S.; BESPALHOK FILHO, J.;C., VIEIRA, L. G. E. Stress induced D1-pyrroline-5-carboxylate synthetase (P5CS) gene confers tolerance to salt stress in transgenic sugarcane. Acta Physiologiae Plantarum, Kraków, v. 36, p. 309-2319, Mai. 2014. https://doi.org/10.1007/s11738-014-1579-8

HEIDARI, M. Variation in seed germination, seedling growth, nucleic acid and biochemical component in canola (Brassica napus L.) under salinity stress. Asian Journal of Plant Science, Faisalabad, v. 8, p. 557-561, Jan. 2009. https://doi.org/10.3923/ajps.2009.557.561

IBGE, 2018. IBGE - Instituto Brasileiro de Geografia e Estatística Disponível em: $<$ https://sidra.ibge.gov.br/tabela/1613\#resultado. Acesso em 18 Jul. 2018.

JESUS, O. N.; OLIVEIRA, E. J.; FALEIRO, F. G.; SOARES, T. L.; GIRARDI, E. A. Illustrated morphoagronomic descriptors for Passiflora spp. editors. - Brasíla, DF: Embrapa, 2017, 122 p.

LARCHER, W. Ecofisiologia vegetal. 1. ed. São Carlos: Rima, 2006. 531p.

LEITE, M. J. H.; GOMES, A. D. V.; SANTOS, R. V. Comportamento inicial do maracujazeiro em solos afetados por sais submetidos a tratamentos alternativos com o uso de coprodutos de mineradoras. Irriga, Botucatu, v. 20, n. 3, p. 401-413, Jun. 2015. https://doi.org/10.15809/irriga.2015v20n3p401 
LIMA, G. S.; GHEYI, H. R.; NOBRE, R. G.; SOARES, L. A. A.; FERNANDES, P. D.; FURTADO, G. F. Trocas gasosas, pigmentos cloroplastídicos e dano celular na mamoneira sob diferentes composições catiônica da água. Irriga, Botucatu, v. 22, n. 4, p. 757-774, Out. 2017a. https://doi.org/10.15809/irriga.2017v22n4p757774

LIMA, L. K. S.; SOARES, T. L.; SOUZA, E. H.; JESUS, O. N.; GIRARDI, E. A. Initial vegetative growth and graft region anatomy of yellow passion fruit on Passiflora spp. Rootstocks. Scientia Horticulturae, Murcia, v. 215, n. 1, p. 134-141, Jan. 2017b. https://doi.org/10.1016/j.scienta.2016.12.001

MARÈ, C.; MICA, E.; CATTIVELLI, L. Molecular advances in rootstock-scion interaction in grapevine. Acta Horticulturae, Leuven, v. 1136, n. 1, p. 155-160, Jul. 2016. https://doi.org/10.17660/ActaHortic.2016.1136.21

MONTAÑA, A. L.; GERHARD, F.; STANISLAV, M.; GUILLERMO, Z. Effect of NaCl salinity on seed germination and seedling emergence of purple passion fruit (Passiflora edulis Sims). Agronomía Colombiana, Bogodá, v. 32, n. 2, p. 188-195, Ago. 2014. https://doi.org/10.15446/agron.colomb.v32n2.38287

MORAIS, L. S. Avaliação das características físico químicas do Passiflora cincinnata em condições ambientes e refrigeradas. 2017. 25p. Trabalho de Conclusão de Curso - Universidade de Brasília Faculdade UNB - Curso de Gestão do Agronegócio, Planaltina -DF, 2017.

MOURA, R. S.; GHEYI, H. R.; COELHO FILHO, M. A.; JESUS, O. N.; LIMA, L. K. S.; CRUZ, C. S. Formation of seedlings of species from the genus Passiflora under saline stress. Bioscence Journal, Uberlândia, v. 33, n. 5, p. 1197-1207, Set. 2017.

MOURA, R. S.; GHEYI, H. R.; COELHO FILHO, M. A.; JESUS, O. N.; SILVA SÁ, F. V.; LIMA, L. K. S. Tolerance of passion fruit species under salt stress. International Journal of Current Research, Patiala, v. 8, n. 9, p. 37689-37695, Set. 2016a. https://doi.org/10.14393/BJ-v33n5a2017-36957

MOURA, R. S.; RIBEIRO, A. A; SIMEAO, M.; SIMAO, L. P. L.; SOUSA, D. R.; SILVA, E. M.; LIMA. C. J. G. S.; SILVA JUNIOR, G. B. Productivity and physico-chemical quality of yellow passion-fruit cultivated under different nitrogen sources through fertigation. International Journal of Current Research, Patiala, v. 8, n.11, p. 42003-42009, Nov. 2016b.

MUNNS, R.; TESTER M. Mechanisms of salinity tolerance. Annual Review of Plant Biology, Palo Alto, v. 59, p. 651-681, 2008. https://doi.org/10.1146/annurev.arplant.59.032607.092911

NASCIMENTO, J. A. M.; CAVALCANTE, L. F.; DANTAS, S. A. G.; MEDEIROS, S. A. S.; DIAS, T. J. Biofertilizante e adubação mineral na qualidade de frutos de maracujazeiro irrigado com água salina. Irriga, Botucatu, v. 20, n. 2, p. 220-232, Jul. 2015. https://doi.org/10.15809/irriga.2015v20n2p220

NASCIMENTO, R. L.; SILVA, J. A. B.; BASSOI, L. H.; PEREIRA, G.; COSTA, B. R. S.; OLIVEIRA, V. S. Trocas gasosas e composição físico-química de vinhos em função de estratégias de irrigação. Irriga, Botucatu, Edição Especial, p. 205-217, Ago. 2016. https://doi.org/10.15809/irriga.2016v1n01p205-217

NEVES, A. L. R.; LACERDA, C. F.; GUIMARÃES, F. V. A.; HERNANDEZ, F. F. F.; SILVA, F. B.; PRISCO, J. T.; GHEYI, H. R. Acumulação de biomassa e extração de nutrientes por plantas de feijão de cordas irrigadas com água salina em diferentes estádios de desenvolvimento. Ciência Rural, Santa Maria, v. 39, p. 758-765, Jun. 2009. https://doi.org/10.1590/S0103-84782009005000014

OLIARI, L. S.; GILES, J. A. D.; MAYRINCK, L. G.; OLIVEIRA, J. P. B.; LOPES, J. C.; OTONI, W. C.; SCHMILDT, E. R.; AOYAMA, E. M.; ALEXANDRE, R. S. Mini-grafting of adult Passiflora edulis Sims f. flavicarpa Deg. scions on to vegetatively propagated adult rootstocks of $P$. mucronata Lam. Australian Journal of Crop Science, Canberra, v. 10, n. 1, p. 490-496, Jan. 2016. 
R Development Core Team. R: A language and environment for statistical computing, Vienna: R Foundation for statistical computing, 2016. Available in: <https://cran.r-project.org/>. Accessed June, 13, 2016.

RAIMUNDO, K.; MAGRI, R. S.; SIMIONATO, E. M. R. S.; SAMPAIO, A. C. Avaliação física e química da polpa de maracujá congelada comercializada na região de Bauru. Revista Brasileira de Fruticultura, Jabuticabal, v. 31, n. 2, p. 539-543, Jun. 2009. https://doi.org/10.1590/S0100-29452009000200031

RIBEIRO, R. V.; MACHADO, E. C.; SANTOS, M. G.; OLIVEIRA, R. F. Photosynthesis and water relations of well-watered orange plants as affected by winter and summer conditions. Photosynthetica, v. 47, n. 2, p. 215-222, Jun. 2009. https://doi.org/10.1007/s11099-009-0035-2

SANTOS, J. L.; MATSUMOTO, S. N.; OLIVEIRA, P. N.; OLIVEIRA, L. S.; SILVA, R. A. Morphophysiological analysis of passion fruit plants from different propagation methods and planting spacing. Revista Caatinga, Mossoró, v. 29, n. 2, p. 305-312, Jun. 2016. https://doi.org/10.1590/198321252016v29n206rc

SCHMILDT, E. R.; OLIARI, L. S.; ALEXANDRE, R. S.; SILVA, F. O. R.; SCHMILDT, O. Histological aspects of mini-grafting of Passiflora edulis Sims. and Passiflora mucronata lam. Revista Brasileira de Fruticultura, Jabuticabal, v. 40, n.2, e-174, Mai. 2018. https://doi.org/10.1590/0100-29452018174

SILVA, E. N.; SILVA, S. L. F.; RIBEIRO, R. V.; SILVEIRA, J. A. G. Comparative effects of salinity and water stress on photosynthesis, water relations and growth of Jatropha plants. Journal of Arid Environments, v. 74, n. 10, p. 1130-1137, Jan. 2010. https://doi.org/10.1016/j.jaridenv.2010.05.036

SILVA, E. N. da; RIBEIRO, R. V.; SILVA, S. L. F.; VIÉGAS, R. A.; SILVEIRA, J. A. G. Salt stress induced damages on the photosynthesis of physic nut young plants. Scientia Agricola, Piracicaba, v. 68, p. 62-68, Fev. 2011. https://doi.org/10.1590/S0103-90162011000100010

SILVA, F. L. B.; LACERDA, C. F.; NEVES, A. L. R.; SOUSA, G. G.; SOUSA, C. H. C.; FEERIRA, F. J. Irrigação com águas salinas e uso de biofertilizante bovino nas trocas gasosas e produtividade de feijão-decorda. Irriga, Botucatu, v. 18, n. 2, p. 304-317, Abr. 2013. https://doi.org/10.15809/irriga.2013v18n2p304

SILVEIRA, J. A. G.; SILVA, S. L. F.; SILVA, E. N.; VIÉGAS, R. A. Mecanismos biomoleculares envolvidos com a resistência ao estresse salino em plantas. In: GHEYI, H. R.; DIAS, N. S.; LACERDA, C. F.; GOMES FILHO, E. (ed.). Manejo da salinidade na agricultura: estudos básicos e aplicados. 2.ed. Fortaleza:

INCTSal. p. 181-196, 2016.

SOUZA, J. T. A.; CAVALCANTE, L. F.; NUNES, J. C.; BEZERRA, F. T. C.; NUNES, J. A. S.; SILVA, A. R.; ORESCA, D.; CAVALCANTE, A. G. Effect of saline water, bovine biofertilizer and potassium on yellow passion fruit growth after planting and on soil salinity. African Journal of Agricultural Research, Pretoria, v. 11, n. 32, p. 2994-3003, Jan. 2016. https://doi.org/10.5897/AJAR2016.11233

SUASSUNA, J. F.; ERNANDES, P. D. F; BRITO, K. S. A.; NASCIMENTO, R.; MELO, A, S.; BRITO, M. E. B. Trocas gasosas e componentes de crescimento em porta enxertos de citros submetidos à restrição hídrica. Irriga, Botucatu, v. 19, n. 3, p. 464-477, Jun. 2014. https://doi.org/10.15809/irriga.2014v19n3p464 